\title{
Determinants of Financial Sustainability in Chinese Firms: A Quantile Regression Approach
}

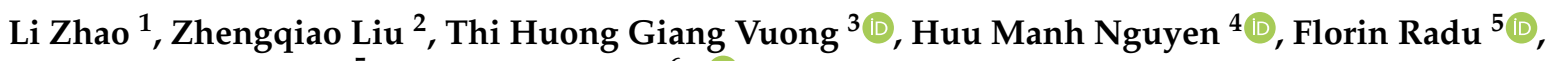 \\ Alina Iuliana Tăbîrcă ${ }^{5}$ and Yang-Che $W u{ }^{6, *(1)}$
}

1 Department of Accounting, Business School, Yango University, Fuzhou 350015, China; hnzl0731@126.com

2 Digital Industry Research Institute of Digital Economy Academy, Yango University, Fuzhou 350015, China; zqliu@ygu.edu.cn

3 Department of Finance, Banking University of Ho Chi Minh, Ho Chi Minh 70000, Vietnam; giangvth@buh.edu.vn

4 Department of Accounting and Finance, Nha Trang University, Nha Trang 57000, Vietnam; manhnh@ntu.edu.vn

5 Faculty of Economics, Valahia University of Targoviste, Str. Aleea Sinaia, nr. 13, 130024 Targoviste, Romania; florinuniv@yahoo.fr (F.R.); alina_tabirca@yahoo.com (A.I.T.)

6 Department of Finance, College of Finance, Feng Chia University, Taichung City 40724, Taiwan

* Correspondence: wuyangche@fcu.edu.tw

check for updates

Citation: Zhao, L.; Liu, Z.; Vuong, T.H.G.; Nguyen, H.M.; Radu, F.; Tăbîrcă, A.I.; Wu, Y.-C. Determinants of Financial Sustainability in Chinese Firms: A Quantile Regression Approach. Sustainability 2022, 14, 1555. https://doi.org/10.3390/ su14031555

Academic Editor: Klaus

Reiner Schenk-Hoppé

Received: 3 December 2021

Accepted: 24 January 2022

Published: 28 January 2022

Publisher's Note: MDPI stays neutral with regard to jurisdictional claims in published maps and institutional affiliations.

Copyright: () 2022 by the authors Licensee MDPI, Basel, Switzerland. This article is an open access article distributed under the terms and conditions of the Creative Commons Attribution (CC BY) license (https:// creativecommons.org/licenses/by/ $4.0 /)$.

\begin{abstract}
Our research investigates the connection between firm characteristics and leverage based on a sample of firms listed in the Chinese Stock Index 300. We aim to examine the sustainability of the financial structure of Chinese enterprises covering the period 2010-2019. We employ a conditional quantile regression that discloses the behavior of regressions across the leverage distribution and compares its results for different leverage levels with those achieved by the linear regression model. The results confirm the effects of the determinants of capital structure change since the quantile of leverage varies. We find that both the trade-off theory (TOT) and the pecking order theory (POT) confirm the validity of Chinese firms' financing decisions at different quantiles of leverage. Specifically, the empirical results support the POT more over the TOT at higher levels of the quantile. Furthermore, the relationship between firm size and leverage strongly switches to support the POT at the highest quantile. All empirical results are obtained from quantile regression, consistent with the prediction for an increase in asymmetric information of the POT when Chinese firms employ more debt in their capital structure.
\end{abstract}

Keywords: financial sustainability; quantile regression; capital structure; financial determinants; pecking order theory; trade-off theory

\section{Introduction}

The capital structure in firms is a central problem because it represents the power and resources that firms hold to allow managers to make financial decisions. Substantial financial resources are conditions that help firms to assume better investment opportunities. Therefore, financial managers pursue maximizing firm value as both motivation and purpose. In general, debt may increase faster than either equity finance or internal financing in firms. Firms can also exploit debt as a debt tax shield term to decrease their corporate income tax.

Scholars consider the celebrated Modigliani-Miller theory proposed in 1958 to be the fundamental capital structure theory. Ref. [1] suppose that the capital structure does not affect firm validity with all the basic assumptions. This theory has made crucial progress on this subject. Today we better understand the most critical research papers that started from the Modigliani and Miller assumptions, making the capital structure relevant to an economic entity's plus value. Yet, very few things remain known about the empirical 
relevance of these theories. Empirical work has revealed some stylized facts about the choice of capital structure. However, this evidence is mostly based on an analysis of U.S. firms, and it is not clear how these facts relate to various theoretical models. Without testing the accuracy of these results outside the environment in which they were discovered, it is difficult to determine whether these empirical regularities are merely false or whether they support one theory or another [2].

It is well known that the agency cost theory forms the foundation of the trade-off theory (TOT). In contrast, the pecking order theory (POT) arises from asymmetric information problems (from the 1980s). The two of these theories are traditional capital structure hypotheses. Corporate finance suggests that these two theories are not mutually exclusive for financial determinations despite being competitive.

The TOT assumes a trade-off between increasing leverage or the increasing cost of financial distress and its tax benefit, which higher debt entails. In turn, it leads to the formation of an optimal capital structure for each firm. Under this theory, there exist adjustment costs, and they lead to a partial adjustment to optimal leverage in each distinct period. The "pecking order" theory explains that the order of resources is more critical than their dimensions. The costs of issuing new securities exceed other considerations. To avoid these costs, companies prefer internal financing, and if the funds attracted are not sufficient, they turn to loans and, ultimately, external financing through equity. If the financing deficit is simply one factor among many that firms have to trade-off, then what is left is a generalized version of the trade-off theory [3]. The TOT can explain why structural capital in firms varies among industries. However, it still cannot explain why profitable firms have lower debt ratios than other firms in the same industry.

Mainly, for the banking and insurance sectors, we note that regulation is stringent and that the value of the enterprises' leverage is always higher than those in the non-financial industry. The bankruptcy cost theory suggests that a leverage lift shows a high probability of bankruptcy [4].

The POT emerged from asymmetric information [5]. as a substitute theory for the TOT. Managers are expected to have more information about their actions than investors and ensure investors' expectations. Managers of highly levered firms will also be less able to consume excessive perquisites since bondholders are inclined to monitor such firms closely. The costs associated may be higher for firms with less collateralizable assets since monitoring such firms' capital outlays is probably more complicated. Therefore, firms with less collateralizable assets may choose higher debt levels to limit perquisite consumption [6].

The POT assumes that firms prefer internal financing for using debt and equity because they suppose that internal financing eliminates the information asymmetry problem over issuing debt and equity. This preference leads to the following pecking order in financing decision-making: using internal financing priority, issuing debt, and issuing equity financing. The pecking order theory can explain why profitable firms usually reach lower debt ratios: these companies have no more external financing needs; it is not because they have low target debt ratios. Thus, the POT can adroitly explain the differences in firms ${ }^{\prime}$ capital structures within industries. Based on the arguments outlined above, either the TOT or the POT offers different capital structure determinants when it affects a firm's leverage.

The year 1978 marks the beginning of Chinese economic innovation. Since then, China has changed its economic performance and the world economic structure. According to World Bank data, China's worldwide ranking for total gross domestic product (GDP) placed it in the fourteenth position in 1978, at the constant price of US\$ in 2010. That is, its GDP was equivalent to only $1.1 \%$ of the global economy. However, by 2010 , the Chinese economy became the world's second-largest economy, with its GDP accounting for 9.2\% of the global economy. By 2017, its GDP reached US\$ $10.2 \mathrm{tn}$, accounting for $12.7 \%$ of the global economy. Aided by sustained growth, the Chinese economy continues to dominate and establish its importance in the global economy. It is now an indispensable contributor to global economic growth. The Chinese Stock Index (CSI 300) includes the 300 largest and 
most liquid A-share stocks-these are domestic shares governed in Renmibi and exchanged in both the Shanghai and Shenzhen stock exchanges. The size of the CSI 300 accounts for more than $60 \%$ of the A-share stocks' total size. It covers all large listed companies in China and some leading enterprises in the industry. The CSI 300 is considered a blue-chip index for Mainland China's stock exchanges. Therefore, financial reports of the 300 listed firms in the stock market help to increase the transparency and objectivity of financial information when evaluating Chinese firms' capital structures.

Thus, we have based this research on a sample of listed firms of the CSI300 index and applied the quantile regression methodology. Our aim is to shed light on which traditional capital structure theory is able to explain the sustainable financial structure of Chinese listed companies as the tendency to use debt increases in Chinese firms. Further, we expand tests to investigate the relationship between debts and the firm features at various leverage ratios.

This study is distinct from the extant literature on Chinese firms because, first, we have used the quantile regression to study the 300 listed firms' capital structures. We have found that the various effects of capital structure determinants are subordinate to the levels of leverage. Second, both the TOT and the POT can explain the capital structure choices of the CSI 300-listed firms at different leverage levels. Following, [7] the financing from retained earnings under the POT helps a firm avoid the asymmetric information problem. Note that this problem mainly arises because firms often issue more debts for financing requirements. Our empirical evidence shows that most capital structure determinants often advocate the POT over the TOT precisely since the leverage moves to higher quantiles. The link between debt ratio and firm size switches to advocate the POT at the highest quantile. Therefore, our results prove the POT's dominance in explaining the Chinese firm's capital structure when the asymmetric information problem increases debt usage. In other words, the predictions of the POT theory sustainably explain the financial structure of Chinese firms over 10 observed years.

This paper is organized into five sections as follows: in Section 2, we discuss the extant literature on the capital structure of firms in different countries, especially China. We describe the empirical methodology, model, and determinants of capital structure in Section 3. In Section 4, we examine all descriptive statistics and analyze the empirical results. The final section presents the conclusions.

\section{Literature Review}

Capital structure is one of the most perplexing puzzles in the financial literature that deals with an optimal mix of debt and equity. While many theories advocate an optimal capital structure for firms, other studies have provided evidence that this view cannot be supported. In later periods, two main views dominated discussions on capital structure in the existing literature. The first of these views is the trade-off theory, which integrates financial distress and agency costs with Modigliani and Miller's earlier models. Trade-off theory aims to balance the bankruptcy and distress costs associated with leveraging the tax benefits from using debt and reducing the agency costs that this creates. The other supported view on capital structure is the pecking order theory, which aligns with firms financial hierarchies and long-term financing strategies. This theory advocates that firms use internal sources, debts, and share issuances in a specific order to meet their funding needs. The reason firms exhibit such behavior stems from the information asymmetry between managers and shareholders [8].

Scholars have often empirically examined the explanatory power of capital structure forms in emerging and developed countries using two corporate finance theories: the TOT and the POT. In this research stream, using capital structure factors to test profitability, fixed assets, non-debt tax shields, growth opportunities, and firm size is prevalent. More recent empirical research also provides adequate evidence that underscores the partial validity of both traditional theories. These results suggest that both the TOT and the POT provide satisfying explanations for the observed firms' capital structures. 
In their article, [2] research capital structure in firms across a group of seven countries. Their research centralizes four capital structure determinants: profitability, fixed assets, market-to-book ratio, and size. They find that the relationship between firm size and tangible assets with debt ratio is consistent with most countries' TOT predictions. However, an adverse effect of profitability on leverage provides evidence to support the POT.

Ref. [7] research on more than 3000 US firms from 1965 to 1999 finds that neither the TOT nor the POT dominates the other in this comparison. They contend that the TOT fails to explain the negative influence of profitability on the levels of debt. In contrast, the POT fails to explain why small firms with low leverage tend to issue more equity when facing higher growth opportunities.

Ref. [9] investigates different types of capital structure determinants for 202 firms listed on the FTSE 250 (London Stock Exchange), with data spanning from 2002 to 2009. The author finds that profitability, liquidity, and volatility are negative and significant concerning leverage. The result, thus, lends further support to the POT. In contrast, firm size and asset structure variables are positive and significant, though the non-debt tax shield is negatively related to the debt ratio. The second result lends support to the static TOT.

Ref. [10] further explains that any capital structure doctrine could have better explanatory power in some instances because these theories cannot be mutually explained by various clusters of firm characteristics used in different capital structure studies. Then, which theory predominates? We ascertain the answer to this question through a review of the following literature.

There exist a substantial number of studies that strongly advocate for the POT. Ref. [11] studies the capital structure of The Philippine's listed firms (1999-2001) in support of the POT. The research finds that leverage and profitability are negatively related, whereas the variance in total liabilities mostly exists in the annual financing deficit. Joint examinations show that there are only relevant values in the pecking order model, where adding explanatory variables for fitted values in the trade-off model is immediately corrected.

Ref. [12] investigate U.S. public firms' capital structures from 1971 to 2001 and effectuate controlling for debt capacity. They indicate that the POT explains the observed financing behavior of a large sample of firms because, on average, the firms used internal funding to finance their investments. Likewise, they find evidence of asymmetric information to support the observed pecking order of financing choices.

There also exist studies that advocate for the TOT. Ref. [13] finds that the advantage of capitalized interest tax shields in U.S. firms (1973-1994) is approximately 10\% in total firm value. However, debts could still increase up to the point where, despite decreasing the incremental benefit of tax, the tax shield's total benefits reach approximately $15 \%$ in total firm value. The existence of debt cost and non-debt tax benefits implies conservatism toward increasing leverage in firms. This result weakly supports the TOT.

Analyzing 16 European countries, [14] provide more robust evidence to support the TOT in capital structure choice compared with the POT. Their results infer that the ability to issue properly timed debt financing related to the degree of interest rates creates the financial flexibility problem. Another important aspect of financial decisions is the earnings per share dilution, reflected in the ability to issue properly timed equity concerning the market of equity. Bancel and Mittoo reveal that important deliberations in capital structure choices occur when firms are uninterested in both the agency costs of debt and asymmetric information.

Ref. [15] also back the TOT's predominance in their study of all U.S. firms comprising the Industrial Annual tapes from 1965 to 2001 but excluding financial and regulated utility firms. Their research focuses on how firms adjust to their target leverage. However, they provide conflicting evaluations regarding when firms decide their capital structures in one way or another. Their results reveal that the POT and market timing theory factors lead to the statistical significance of parameters. However, their economic effects are swamped by the movement toward a firm's target debt ratio. 
Compared to conventional models such as linear regression or generalized moments, recent studies in capital structure employ quantile regression. The resulting conclusions are even more remarkable. Ref. [16] surveys the process and factors of firms' capital structures in Korea. The author concentrates on the distinctions of firms at different levels of debt allocation. According to the results, highly leveraged firms may desire to stay far from an upper debt constraint by using other financing sources [16]. Because firms continue increasing debts, they are eventually unable to borrow more, regardless of their size or increase in their collaterals. Hence, the capital structure determinants may have negligible effects in high quantiles, but they remain influential at low and moderate leverage.

Using quantile regression to investigate the indebtedness determinants for Brazilian firms between 2000 and 2009, [17] argue that different leverage quantiles are tied with different levels of bankruptcy and agency costs. They affirm that the effect of capital structure determinants varies, being subordinate to the debt distribution. Lower leverage is broadly synonymous with lower bankruptcy costs. Hence, determinants that encourage debt usage may prove significant or more strongly influential than higher debt quantiles coupled with higher bankruptcy costs. Their results for the variable of size or profitability strongly support the POT, becoming more relevant as we move to higher quantiles.

Ref. [18] applies the quantile regression to a study on company leverage in Spain from 2001 to 2011. The author verifies the heterogeneous effects of leverage determinants. Unlike [16] and [17], Sánchez-Vidal demonstrates that many determinants cannot remain significant in the case of highly leveraged companies.

Ref. [19] use the quantile regression to research Vietnamese listed firms (excluding financial firms) from 2006 to 2015. Compared with traditional panel data methods, the nonlinear correlation between capital structure determinants and leverage varies at different quantiles.

Ref. [20] use a partial adjustment model to survey the behavior of capital structure determinants and macroeconomic conditions across all distributions of leverage levels (including total debt, long-term debt, and short-term debt) in U.S. firms from 1970 to 2014. They determine whether long- or short-term debt ratios change regarding their partial adjustment speeds. According to the results, the long-term debt ratio decreases when the short-term debt ratio increases.

In most of the literature above, the influence of capital structure determinants on leverage changes with their highlighted contributions when the leverage switches between quantile levels. However, they fail to determine the dominance of either the POT or the TOT in explaining the capital structure, especially since firms tend to finance through more debt, leading to an increase in asymmetric information.

The extant literature on capital structure determinants in Chinese firms also reveals ambiguous results. Ref. [21] surveys 88 listed companies in the Dow-China 88 Index (1995-2000) to establish that the capital structure choice decision complies with a new pecking order of using capital as the first retained earnings, followed by long-term equity debt. Ref. [22] focus on the top 50 Chinese companies for 2002 and 2003. Their discoveries broadly support the POT over the TOT, but only the firm size variable supports the latter theory.

Ref. [23] analyzes data, including both market and accounting data from the year 1994 to 2003, with a sample of more than 1200 Chinese listed firms. Using an ordinary least squares (OLS) estimation, they find that the level of debt in Chinese firms is positively correlated with the variables of firm size and fixed assets, but negatively correlated with the variables of profitability, non-debt tax shields, growth opportunity, and managerial shareholdings as related to industries.

Analyzing the capital structure of 92 information technology firms (I.T.) in China from the year 2004 to 2007, [24] establish whether the POT or the TOT can explain the capital structure of Chinese I.T. firms. Ref. [25] examines the stock market's capital structure determinants using a cross-section sample of 1481 Chinese non-financial firms in 2001. Unlike extant studies, the author inspects the effect of determinants on capital structure, 
owner state effect, and contemporary industry effect. Large firms usually use financial leverage at a high level because of their better debt liquidity, which is suitable under the TOT [3].

Ref. [26] tests the firm characteristics and adjustment speed of capital structure from 2008 to 2013 in the Chinese market using the generalized combination method of moments and dynamic panel method. The author finds that profitability is still not the primary determinant for debt leverage. Contrariwise, the effect of both variables-non-debt tax shield and firm size-is significant. At the same time, it is suggested that the three key firm characteristics are liquidity, firm size, and a non-debt tax shield, which is a significant difference from previous studies. Further, Yang indicates that both employee productivity and employment size are also significant capital structure determinants.

Ref. [27] examine the stability of the corporate capital structure in Chinese listed firms covering the period 1990-2013. They employ the fixed-time effects regression model on panel data. Their paper demonstrates that size, profitability, and investment opportunity variables significantly influence the capital structure, whereas the effect of the tangible assets variable is found to be insignificant. Further, industry differences are unlikely to be significant in explaining differences and variations in debt ratios. Similarly, [28] analyze the impact of firm characteristics on the corporate capital structure of Chinese firms. Their difference is that they use dynamic models to determine the debt maturity structure of Chinese firms. From another perspective, [29] and [30] show that the development of the bond market has significantly influenced the capital structure of Chinese firms in recent years. Prior studies have identified that many factors associated with the capital structure may differ in the long and short term. For this reason, the long and short-term association of these factors and debt ratios may be estimated with the use of fixed-effects estimators. The results show that the size of a company is positively associated with debt ratios in the long run. In contrast, profitability, growth opportunities, and the non-debt tax shield are all negatively related. In the short term, the firms' sizes, tangibility of assets, and the industry median debt ratio positively associate with the debt ratios. At the same time, profitability and the non-debt tax shield are negatively related to debts in firms [31].

Recently, new insights were added by using a firm's performance as a measure of the impact of different proxies for capital structure. Some studies in different countries have examined the direct effect of using different types of debts on a firm's performance. Most studies reported a negative relationship between debts and a firm's performance [32].

Overall, most studies find a positive correlation between fixed assets (firm scale) and leverage, whereas the non-debt tax shield correlates inversely with the difference in leverage levels. This relation indicates the predominance of the TOT in capital structure choices. However, TOT still cannot explain the negative relationship between profitability and financial leverage. Ref. [7] suppose that each capital structure theory cannot wholly explain the predictions of a firm's financing decisions. For instance, the POT is unsuccessful in explaining why small firms with low leverage have large equity issues when facing growth opportunities. In contrast, the TOT cannot explain the negative relationship between debt and profitability.

In summary, there is a vast gap in the current papers on corporate financial structure, which is that previous studies have not used quantile regression to consider the sustainability of the POT or TOT theories in explaining a firm's financial structure at different quantile levels. It is vital when corporate managers determine the relationship between firms' financial leverage and internal factors when enterprises use debt at various levels. Hence, we use the quantile regression to estimate the effect of independent variables on the dependent variable at different conditional distributions, extended from the traditional linear regression [33]. Our purpose is to investigate the sustainability of the financial structure of Chinese enterprises in the period 2010-2019. 


\section{Methodology, Model, and Determinants of Capital Structure}

\subsection{Methodology}

Ordinary least squares (OLS) regression is a linear regression that estimates the unknown coefficient of independent variables by the least-squares principle. All variables yield results that are estimated by only one measure of the central distribution. We do not consider extreme cases or tail behaviors. OLS estimations are likely inefficient and biased because financial data are heterogeneous, non-normally distributed, and contain large outliers. Because the relationship between firm characteristics and capital structure may exhibit nonlinearities, the OLS model offers less information about the estimated results [16]. Quantile regression (QR) was initially presented as a 'robust' regression method that permits estimation where the specific hypothesis of normality of the error term might not be strictly satisfied [20]. The OLS estimator focuses solely on a measure of central tendency, while Q.R describes data better because it analyzes the level of leverage by quantile [17]. Quantile regression is useful to comprehensively study the dynamic relationship between a firm's capital structure and its determinants. Ref. [34] also demonstrate and compare the essential differences between linear and quantile regressions (see Table 1 for more details).

Table 1. Comparison of Linear Regression and Quantile Regression.

\begin{tabular}{|c|c|}
\hline Linear Regression & Quantile Regression \\
\hline Predicts the conditional mean E (y/x) & Predicts conditional quantiles Quant ${ }_{\theta}(y / x)$ \\
\hline Applies when $n$ is small & Needs sufficient data \\
\hline Often assumes normality & Is distribution agnostic \\
\hline Doesn't preserve $E(y / x)$ under transformation & Preserves Quant $_{\theta}(\mathrm{y} / \mathrm{x})$ under transformation \\
\hline Is sensitive to outliers & Is robust to response outliers \\
\hline Is computationally inexpensive & Is computationally intensive \\
\hline
\end{tabular}

Hence, we use quantile regression to estimate the effect of independent variables on a dependent variable at different conditional distributions, extended from the traditional linear regression [33]. Let $\left(y_{i}, x_{i}\right)$, where $i=1,2,3 \ldots$, and $\mathrm{N}$ is the number of observations from the population. Here, $x_{i}$ is a $(\mathrm{K} x 1)$ vector of regressions. We construct the conditional quantile regression model with the assumption that the $\theta$ th quantile of the conditional distribution of $y_{i}$ is linear in $x_{i}$.

$$
\begin{gathered}
y_{i}=\alpha_{\theta} x_{i}{ }^{\prime}+u_{i, \theta} \\
\operatorname{Quant}_{\theta}\left(y_{i} \mid x_{i}\right)=\inf \left\{y: F_{i}(y \mid x) \theta\right\}=\alpha_{\theta} x_{i}{ }^{\prime}, \\
\operatorname{Quant}_{\theta}\left(u_{i, \theta} \mid x_{i}\right)=0,
\end{gathered}
$$

where Quant $_{\theta}\left(y_{i} \mid x_{i}\right)$ denotes the $\theta$ th conditional quantile of $y_{i}$ on the regression vector $x_{i} ; \alpha_{\theta}$ denotes the unaware vectors of coefficients to be estimated for different values of $\theta$ in $(0,1)$; and $u_{\theta}$ is the error term, which is assumed to have a continuously differentiable cumulative distribution function. $F_{u \theta}(. \mid x)$ and density function $f_{u \theta}(. \mid x) . F_{i}(. \mid x)$ indicate the conditional distribution function of $y$. Because we transform the value of $\theta$ from 0 to 1 , we inspect the entire distribution of the $y$ dependent variable conditional on the $x$ independent variable. We obtain the estimation for parameter $a_{\theta}$ as follows:

$$
\min \sum_{i}^{n} p_{\theta}\left(y_{i}-\alpha_{\theta} x_{i}^{\prime}\right)
$$

where $p_{\theta}(u)$ is the "check function", which, in turn, is defined as:

$$
p_{\theta}(u)=\left\{\begin{array}{l}
\theta u \text { if } u \geq 0 \\
(\theta-1) u<0
\end{array} .\right.
$$


Despite having an indistinct form of estimation, linear engineering programs can manage the problem of minimizing results [33]. Ref. [35] exploits this method to estimate models with censoring to extend the quantiles comprehensively. Scholars have used quantile regression as an available bootstrap method in statistical analysis software, such as STATA, in more recent research. These are standard methods designed to estimate the coefficients' asymptotical covariance matrix [36]. In our study, we use the quantile regressions to survey whether the determinants' effects are distinguishable across the quantiles in the dependent variable's conditional distribution, and then combine it with the bootstrap method with 1000 replications. We deem this method useful for three reasons. First, the design matrix of the bootstrap executes its task in small sample sizes. The number of observed Chinese firms is 10 times smaller than the popular sample. Second, the bootstrap method helps the asymptotically inconsistent estimation converge to the original sample's distribution. Third, the parity of slope coefficients at different quantiles can be tested by bootstrap methods. We specify the panel data model as follows:

$$
\operatorname{Quant}_{\theta}\left(y_{i, t} \mid x_{i, t}\right)=\alpha_{0}+\alpha_{\theta}^{\prime} x_{i, t}
$$

where $y_{i, t}$ is the dependent variable at the $\theta$ th quantile, $x_{i, t}$ denotes the independent variables at the $\theta$ th quantile, $\alpha_{0}$ and $\alpha_{\theta}{ }^{\prime}$ are the intercept and slope of estimation of $y_{i, t}$ according to $x_{i, t}$ at quantile $\theta$ th, respectively, and $t=1,2, \ldots T$ and $i=1,2, \ldots N$.

\subsection{Model and Determinants of Capital Structure}

In this section, we propose the empirical model that accounts for the nature of the capital structure. We take $L E V$ as the debt ratio or leverage, defined by total debts divided by total assets [21]. Supposing a firm has its target leverage, its leverage will be adjusted toward the target. Change in the leverage ratio, $L E V_{i, t}-L E V_{i, t-1}$, denotes the disparity between the target leverage $\left(L E V_{i, t}{ }^{*}\right)$ and lagged leverage $\left(L E V_{i, t-1}\right)$.

$$
\left(L E V_{i, t}-L E V_{i, t-1}\right)=\alpha^{*}\left(L E V_{i, t}^{*}-L E V_{i, t-1}\right),
$$

where $L E V_{i, t}^{*}$ is the target leverage of firm $i$ in year $t$. The coefficient $\alpha$ is the speed of adjustment to the target leverage; it varies between 0 and 1 . This ensures that the leverage target exists in firms. The TOT supposes an optimum level of debt, which is the company's target for each period. Contrariwise, the POT argues that there is no target leverage in the firm. Instead, the leverage changes over each period, depending on its profitability and growth opportunity.

According to [16], the unobservable target leverage is modeled as a linear correlation of capital structure determinants such as profitability (PROF), tangible assets (TANG), non-debt tax shields (NDTS), growth opportunities (GROWTH), and firm size (SIZE).

$L E V_{i, t}{ }^{*}=\alpha_{0}+\alpha_{1}{ }^{*} \mathrm{PROF}_{i, t}+\alpha_{2}{ }^{*} \mathrm{TANG}_{i, t}+\alpha_{3}{ }^{*} \mathrm{NDTS}_{i, t}+\alpha_{4}{ }^{*} \mathrm{GROWTH}_{i, t}+\alpha_{5}{ }^{*} \mathrm{SIZE}_{i, t}+\mu_{i, t}$

The predicted profitability has a positive effect on leverage by the TOT. This supposes that profitable firms prefer using debt to use the payoffs from the debt tax shield. With more profitability, firms reduce both bankruptcy and exhaustion costs. Otherwise, the POT predicts that firms prefer to employ internal financing, followed by debt and equity financing. Less profitable firms with weak cash flow issue external funds more readily when they face an adequate investment opportunity. Hence, the POT predicts that profitability has an inverse relation with leverage. Following $[9,12,25]$, we contend that profitability is measured by earnings before interest and taxes and divided by total assets.

The variable of tangible assets positively correlates with the level of debt in most studies because: (1) [37] suppose that fixed assets can be exploited as collateral assets. Such assets may alleviate a creditor's risk of incurring liabilities when borrowers fall into bankruptcy. (2) [38], lenders believe that the validity of tangible assets is comparable with intangible assets under bankruptcy circumstances. They suppose that leverage could 
increase with the liquidation value of assets. Ref. [2] employ tangible assets to reduce the agency costs of debt because they are easy to collateralize. Ref. [39] suppose that firms suffer more asymmetric information if they own more tangible assets. Therefore, they borrow debt than issue equity for financing requirements. In smaller firms, more asymmetric information may also make firms use more fixed assets. Thus, both the TOT and the POT predict a positive relationship between tangible assets and debt ratios. In this study, we measure the tangible assets variable as the tangible assets by dividing total fixed assets by the total assets ([21,23], $2008[9,40])$.

Only the TOT predicts the effect of a non-debt tax shield on leverage. It supposes that an optimized structural capital is possible once a trade-off between the interest tax shield and bankruptcy has been made. Firms reduce tax debt by employing a tax shield, such as depreciation or investment tax credit terms. This theory predicts an inverse relationship between the levels of debt and non-debt tax shield in firms [41]. Ref. [42] uses a non-debt tax shield-depreciations divided by total assets-and finds a negative link between non-debt tax shields and leverage. Instead, the POT does not predict any relationship between tax shields and leverage. Following $[9,42]$, we measure the non-debt tax shield variable as the total depreciation divided by total assets.

The TOT suggests that growth opportunity is negatively associated with leverage because higher growth opportunity leads to greater bankruptcy risk [43]. Contrary to the TOT, the POT predicts a positive correlation between leverage and growth opportunity because more investment opportunities need more financing resources. This leads to the use of more debt when internal financing is exhausted. Because information asymmetries exist more in scenarios of investment opportunities than assets in place, following the POT, firms with more significant growth opportunities tend to issue debt over equity [7]. Herein, we calculate the growth opportunity variable by using the growth rate of total assets [21].

Ref. [44] argues that the costs of debt may be higher for smaller companies. That is, these costs have an essential effect on the borrowing decisions of small companies. Hence, the TOT suggests a positive effect of firm size on the levels of debt. Contrariwise, the POT supposes that firm size is an asymmetric information barrier for outside investors seeking to access all management information. Ref. [2] suppose that, for larger-scale firms, the more complex the organization is, the higher the costs of information are. Hence, the POT suggests a negative relationship between debt ratio and firm size. We, thus, denote the variable of firm size variable by the logarithm of total assets, one of three measures used by Chongyu [45] to examine the effect of various firm size measures on capital structure. All variables in our research are measured by book value because we only examine the TOT and POT's explanatory powers without the market timing theory.

Combining Equation (2) with Equation (1), we obtain Equation (3):

$L E V_{i, t=} \alpha \alpha_{0}+(1-\alpha)^{*} L E V_{i, t-1}+\alpha \alpha_{1}{ }^{*} P R O F_{i, t}+\alpha \alpha_{2}{ }^{*} \operatorname{TANG}_{i, t}+\alpha \alpha_{3}{ }^{*} \operatorname{NDTS}_{i, t}+\alpha \alpha_{4}{ }^{*} \mathrm{GROWTH}_{i, t}+\alpha \alpha_{5}{ }^{*} \mathrm{SIZE}_{i, t}+\tau_{i, t}$

We use quantile regression to analyze capital structure data by following Equation (3). The changes of estimated coefficients will reveal how the capital structure determinants affect leverage across the conditional distribution of leverage or quantile levels. Next, we conduct an empirical analysis and summarize our results.

Table 2 presents the key variables that have been investigated in this research. Each of these determinants affects the capital structure predicted by the pecking order and trade-off theories [46]. 
Table 2. Capital structure determinants.

\begin{tabular}{|c|c|c|}
\hline Determinant & Description & Reference \\
\hline Profitability & $\begin{array}{l}\text { Profitability plays an essential role in making decisions on leverage. In } \\
\text { trade-off theory, taxes, agency costs, and bankruptcy costs push more } \\
\text { profitable firms toward a higher book leverage. First, this is due to a decline in } \\
\text { the expected bankruptcy costs when profitability is high. Second, the } \\
\text { deductibility of corporate interest payments makes more firms finance with } \\
\text { debt. When firms are profitable in a trade-off theory framework, they prefer } \\
\text { debt to the benefit of a tax shield. }\end{array}$ & PROF \\
\hline Tangible assets & $\begin{array}{l}\text { The nature of a firm's assets impacts the capital structure. In case of } \\
\text { bankruptcy, tangible assets are less subject to informational asymmetries } \\
\text { because they have a more excellent value than intangible ones. Therefore, } \\
\text { moral hazard risks are reduced when the firm offers tangible assets as } \\
\text { collateral because this constitutes a positive signal to creditors. }\end{array}$ & TANG \\
\hline Non-debt tax shields & $\begin{array}{l}\text { Many firms tend to use tax shields even though interest is tax-deductible due } \\
\text { to default risk. Some certain tax deductions are to be made from a company's } \\
\text { taxable income, allowed by tax laws. Depreciation on tangibles and intangibles } \\
\text { is also tax-deductible. To determine the capital structure choice, the effective } \\
\text { tax rate must be used as a determinant. }\end{array}$ & NDTS \\
\hline Growth opportunity & $\begin{array}{l}\text { The trade-off theory suggests that firms with investment opportunities have } \\
\text { less leverage because they have more substantial incentives to avoid } \\
\text { under-investment and asset substitution that can arise from } \\
\text { stockholder-bondholder agency conflicts. Therefore, the trade-off theory } \\
\text { predicts a negative relationship between leverage and } \\
\text { investment opportunities. }\end{array}$ & GROWTH \\
\hline Firm size & $\begin{array}{l}\text { The trade-off theory suggests an inverse relationship between size and the } \\
\text { probability of bankruptcy, i.e., a positive relationship between size and } \\
\text { leverage. However, the capital structure's pecking order theory predicts a } \\
\text { negative relationship between size and leverage; that is, a larger firm exhibits } \\
\text { an increasing preference for equity relative to debt. }\end{array}$ & SIZE \\
\hline
\end{tabular}

\section{Data and Empirical Results}

\subsection{Data}

Our study exploits data from 300 Chinese listed firms' annual accounting statements, covering the period 2010-2019 in the Taiwan Economic Journal database. A list of 300 listed firms is taken from the CSI 300 on the website: http:/ / www.csindex.com.cn, accessed on 27 November 2017. The financial firms have a striking difference in capital structure compared with the non-financial firms. We, thus, excluded financial firms and, further, dropped firms that miss any observations for variable estimations in the examined period. Our final sample includes a balanced panel sample of 221 firms over 8 years.

\subsection{Empirical Results}

Table 3 reports that the average debt ratio for the full sample is 0.4880 . The mean profitability is 0.0710 , the mean of tangible assets is 0.3616 , the average of the non-debt tax shield is 0.2741 , and the mean of growth opportunity is 0.2924 . The variables LEV, PROF, TANG, NDTS, and GROWTH are non-normally distributed, except for SIZE, when considering the kurtosis and skewness indicators. However, the standard deviation of the SIZE variable is relatively high. Thus, the OLS regression is less effective when examining the effect of capital structure determinants on leverage. We expect that quantile regression will yield more interesting results at different levels of debt.

Table 4 reports the correlation coefficients for LEV, PROF, TANG, NDTS, GROWTH, and SIZE. LEV correlates positively with TANG, NDTS, and SIZE, whereas it correlates negatively with PROF and GROWTH. TANG correlates positively with NDTS (correlation coefficient, 0.6231) and SIZE (correlation coefficient, 0.4124). To avoid multicollinearity, we removed TANG from Equation (3) when running the quantile regression. 
Table 3. Descriptive statistics of the variables used.

\begin{tabular}{ccccccc}
\hline & LEV & PROF & TANG & NDTS & GROWTH & SIZE \\
\hline Mean & 0.4880 & 0.0710 & 0.3616 & 0.2741 & 0.2924 & 17.0281 \\
Median. & 0.5020 & 0.0589 & 0.3539 & 0.1659 & 0.1435 & 16.9827 \\
Maximum & 2.5785 & 0.6674 & 0.9005 & 2.2438 & 11.9419 & 21.6010 \\
Minimum & 0.0075 & -3.8889 & 0.0000 & 0.0000 & -0.7867 & 12.0764 \\
Std. Dev. & 0.2172 & 0.1202 & 0.1813 & 0.3022 & 0.7835 & 1.5300 \\
Skewness & 0.4334 & -20.2723 & 0.2738 & 2.5784 & 8.5295 & 0.0195 \\
Kurtosis & 8.0981 & 670.3990 & 2.4667 & 12.1222 & 94.9804 & 3.0653 \\
Observations & 1768 & 1768 & 1768 & 1768 & 1768 & 1768 \\
\hline
\end{tabular}

Table 4. Correlations, $p$-value of correlations between variables.

\begin{tabular}{ccccccc}
\hline $\begin{array}{c}\text { Correlation } \\
(p \text {-Value })\end{array}$ & LEV & PROF & TANG & NDTS & GROWTH & SIZE \\
\hline LEV & 1.0000 & & & & \\
PROF & $-0.4510^{* * *}$ & 1.0000 & & & \\
TANG & $(0.0000)$ & $\overline{-}$ & & & \\
& $0.3264^{* * *}$ & $-0.1214^{* * *}$ & 1.0000 & & \\
NDTS & $(0.0000)$ & $(0.0000)$ & - & & \\
& $0.0970^{* * *}$ & $-0.0909^{* * *}$ & $0.6231^{* * *}$ & 1.0000 & \\
GROWTH & $(0.0000)$ & $(0.0001)$ & $(0.0000)$ & $\overline{ }$ & \\
& $-0.1006^{* * *}$ & $0.0887^{* * *}$ & $-0.2012^{* * *}$ & $-0.1516^{* * *}$ & 1.0000 & \\
SIZE & $(0.0000)$ & $(0.0002)$ & $(0.0000)$ & $(0.0000)$ & - & \\
& $0.5487^{* * *}$ & $-0.1572^{* * *}$ & $0.4124^{* * *}$ & $0.2965^{* * *}$ & $-0.1612^{* * *}$ & 1.0000 \\
\hline
\end{tabular}

Note: $p$-value is in parentheses ()$.{ }^{* * *}$ represent the significance at the $1 \%$ levels.

In Table 5, we consider the variation trend of firm-characteristic variables at different quantiles of the leverage distribution. Profitability tends to diminish when we raise the portion of leverage; in fact, the highest quantile yields negative profitability. Contrariwise, firm size increases with incremental leverage. Finally, tangible assets and growth opportunities are somewhat similar across the various distributions of debt ratio. Similar comments may be implied for either the non-debt tax shield's volatility trend or the depreciation in proportion to the total assets.

Table 5. Firm characteristics at different parts of the leverage distribution.

\begin{tabular}{ccccccccccc}
\hline Quantiles & $<\mathbf{0 . 1}$ & $\mathbf{0 . 1 - 0 . 2}$ & $\mathbf{0 . 2 - 0 . 3}$ & $\mathbf{0 . 3 - 0 . 4}$ & $\mathbf{0 . 4 - 0 . 5}$ & $\mathbf{0 . 5}-\mathbf{0 . 6}$ & $\mathbf{0 . 6 - 0 . 7}$ & $\mathbf{0 . 7 - 0 . 8}$ & $\mathbf{0 . 8}-\mathbf{0 . 9}$ & $>\mathbf{0 . 9}$ \\
\hline Obs. & 177 & 177 & 177 & 177 & 176 & 177 & 177 & 177 & 177 & 176 \\
LEV & 0.1096 & 0.2393 & 0.3320 & 0.4086 & 0.4733 & 0.5343 & 0.5981 & 0.6568 & 0.7097 & 0.8202 \\
PROF & 0.1270 & 0.11857 & 0.1151 & 0.0841 & 0.0771 & 0.0609 & 0.0532 & 0.0388 & 0.0372 & -0.0022 \\
TANG & 0.2103 & 0.3048 & 0.3358 & 0.3450 & 0.3726 & 0.3822 & 0.3759 & 0.4056 & 0.4537 & 0.4307 \\
NDTS & 0.1711 & 0.2808 & 0.2294 & 0.2516 & 0.3449 & 0.3099 & 0.2917 & 0.2724 & 0.3253 & 0.2647 \\
GROWTH & 0.5668 & 0.2272 & 0.3799 & 0.2797 & 0.2261 & 0.2711 & 0.2209 & 0.2581 & 0.2180 & 0.2753 \\
SIZE & 15.2236 & 16.1143 & 16.3605 & 16.7748 & 16.9808 & 17.3021 & 17.4941 & 17.5861 & 18.0475 & 18.4047 \\
\hline
\end{tabular}

Table 6 reports the estimations of the quantile regression of $L E V$ on $L E V_{-1}, P R O F$, NDTS, GROWTH, and SIZE. The coefficients based on the different quantiles of leverage vary and are appreciably different from the OLS estimation. As per the evidence, the capital structures of the firms listed in the CSI 300 more strongly tend toward the POT at the high quantile leverage than at the low quantile leverage (we offer a detailed analysis below). 
Table 6. Determinants of firm leverage.

\begin{tabular}{|c|c|c|c|c|c|c|c|c|}
\hline \multirow{2}{*}{ Quantile } & \multirow{2}{*}{ INTERCEPT } & \multirow{2}{*}{$L E V(-1)$} & \multirow{2}{*}{ PROF } & \multirow{2}{*}{ NDTS } & \multirow{2}{*}{ GROWTH } & \multirow{2}{*}{ SIZE } & \multicolumn{2}{|c|}{$\begin{array}{l}\text { Statistic Tests of the Equality of Slope } \\
\text { Estimates Across Various Quantiles }\end{array}$} \\
\hline & & & & & & & Quantiles & $\begin{array}{l}\text { F-Statistic } \\
(p \text {-Value })\end{array}$ \\
\hline 0.1 & $-0.2558(0.0000)^{* * *}$ & $0.8562(0.0000)^{* * *}$ & $-0.2932(0.0295) * *$ & $-0.0571(0.0000)^{* * *}$ & $-0.0776(0.0000)^{* * *}$ & $0.0180(0.0000)^{* * *}$ & 0.1 versus 0.9 & $35.65(0.0000) * * *$ \\
\hline 0.2 & $-0.1396(0.0000)^{* * *}$ & $0.8768(0.0000)^{* * *}$ & $-0.3017(0.0000)^{* * *}$ & $-0.0350(0.0000) * * *$ & $-0.0022(0.5090)$ & $0.0116(0.0000)^{* * *}$ & 0.2 versus 0.8 & $26.81(0.0000)^{* * *}$ \\
\hline 0.3 & $-0.0808(0.0000)^{* * *}$ & $0.8922(0.0000)^{* * *}$ & $-0.2824(0.0000)^{* * *}$ & $-0.0272(0.0000) * * *$ & $0.0104(0.0009)^{* * *}$ & $0.0082(0.0000)^{* * *}$ & 0.3 versus 0.7 & $21.50(0.0000)^{* * *}$ \\
\hline 0.4 & $-0.0331(0.1429)$ & $0.8893(0.0000)^{* * * *}$ & $-0.3122(0.0000)^{* * *}$ & $-0.0261(0.0000)^{* * *}$ & $0.0222(0.0062) * * *$ & $0.0062(0.0000)^{* * *}$ & 0.4 versus 0.6 & $7.62(0.0000)^{* * *}$ \\
\hline 0.5 & 0.0067 (0.7503) & $0.8785(0.0000)^{* * *}$ & $-0.3660(0.0000) * * *$ & $-0.0202(0.0005)^{* * *}$ & $0.0516(0.0000)^{* * *}$ & $0.0048(0.0003)^{* * *}$ & & \\
\hline 0.7 & $0.0788(0.0001)^{* * *}$ & $0.8587(0.0000)^{* * *}$ & $-0.4325(0.0000)^{* * *}$ & $-0.0129(0.0101)^{* *}$ & $0.1063(0.0057) * * *$ & $0.0020(0.0724)$ * & & \\
\hline 0.8 & $0.1096(0.0000) * * *$ & $0.8390(0.0000)^{* * *}$ & $-0.4745(0.0000)^{* * *}$ & $-0.0121(0.0014)^{* * *}$ & $0.1464(0.0000) * * *$ & $0.0012(0.2698)$ & & \\
\hline 0.9 & $0.1928(0.0000)^{* * *}$ & $0.8076(0.0000)^{* * *}$ & $-0.5492(0.0000)^{* * *}$ & $-0.0072(0.0000) * * *$ & $0.1645(0.0000)^{* * *}$ & $-0.0018(0.0998)$ * & & \\
\hline OLS & $-0.0512(0.0379)^{* *}$ & $0.7794(0.0000)^{* * *}$ & $-0.4730(0.0000)^{* * *}$ & $-0.0402(0.0000) * * *$ & $0.0048(0.0919) *$ & $0.0121(0.0000)^{* * *}$ & & \\
\hline
\end{tabular}

${ }^{* * *}$ represent the significance at the $1 \%$ levels, ${ }^{* *}$ represent the significance at the $5 \%$ levels, ${ }^{*}$ represent the significance at the $10 \%$ levels. 
Table 6 reports the results of Equation (3): $L E V_{i, t}=\alpha \alpha_{0}+(1-\alpha)^{*} L E V_{i, t-1}+\alpha \alpha_{1}{ }^{*} P R O F_{i, t}$ $+\alpha \alpha_{2}{ }^{*} \mathrm{TANG}_{i, t}+\alpha \alpha_{3}{ }^{*} \mathrm{NDTS}_{i, t}+\alpha \alpha_{4}{ }^{*} \mathrm{GROWTH} H_{i, t}+\alpha \alpha_{5}{ }^{*} S I Z E_{i, t}+\tau_{i, t}$. We use both quantile regression at $0.1 \mathrm{th}, 0.2 \mathrm{th}, 0.3 \mathrm{th}, 0.4 \mathrm{th}, 0.5 \mathrm{th}, 0.6 \mathrm{th}, 0.7 \mathrm{th}, 0.8 \mathrm{th}, 0.9 \mathrm{th}$ and OLS regression to estimate the impact of capital structure determinants on leverage. However, we skipped the TANG variable from Equation (3) to avoid the multicollinearity problem. We use F-tests for the parity of slope parameters and the corresponding P-values at pairs of quantiles. All bootstrap simulations are based on 1000 replications.

We also plot the quantile regression $(0.1,0.2,0.3,0.4,0.5,0.6,0.7,0.8,0.9)$ and the OLS regression, with their respective 95\% confidence intervals, for all variables in Figure 1. These graphs correspond to the different results between the quantile regression estimation and the OLS estimation for all independent variables at least in one quantile in Table 5.

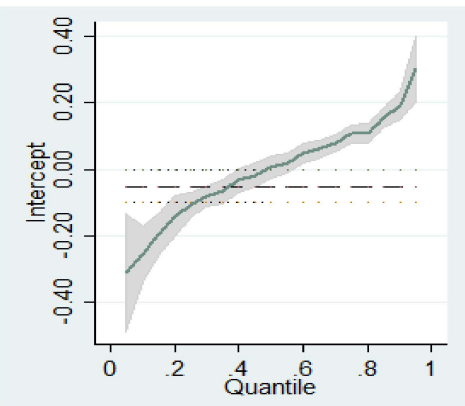

a. Estimated coefficient: INTERCEPT

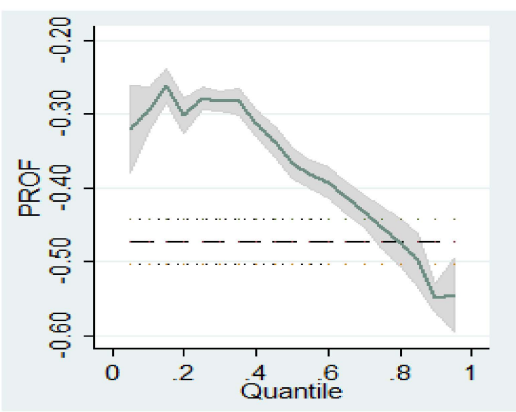

c. Estimated coefficient: PROF

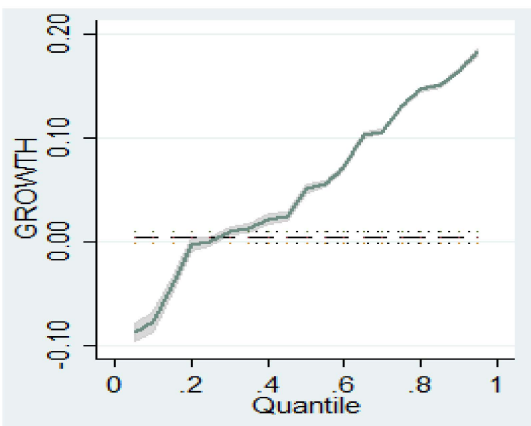

e. Estimated coefficient: GROWTH

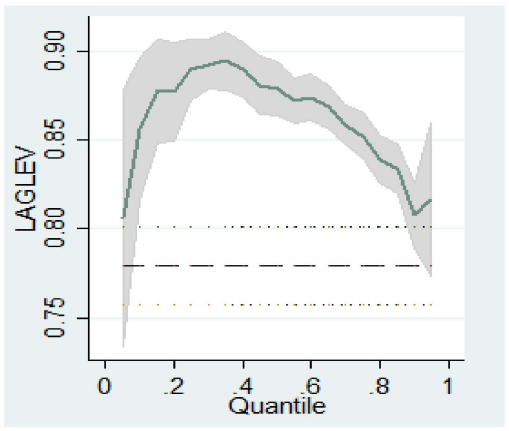

b. Estimated coefficient: $L E V-1$

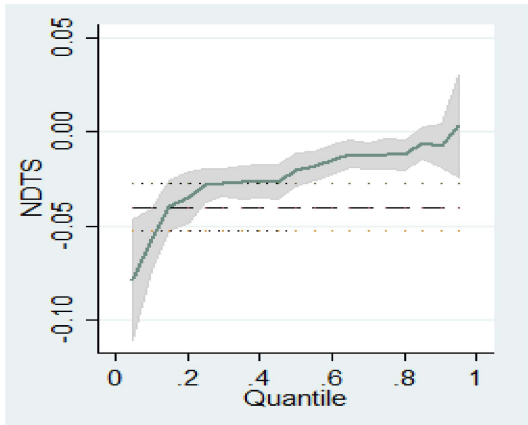

d. Estimated coefficient: NDTS

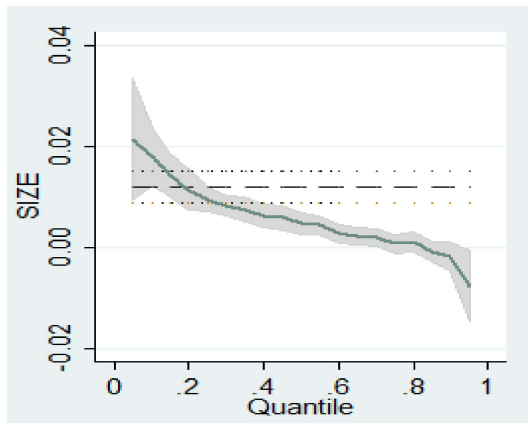

f. Estimated coefficient: SIZE

Figure 1. Estimated coefficients of capital structure determinants and $95 \%$ confidence interval. Note: LAGLEV is lagged one period of the LEV variable. Black line (OLS) and dashed area (95\% OLS), blue line (Q.R) and shaded area (95\% of Q.R). (For further interpretation of the references in this figure legend, the reader is referred to the web version of the article).

Figure 1 illustrates five plots: Plot A (estimated coefficient of INTERCEPT), Plot B (estimated coefficient of $L E V_{-1}$ variable), Plot $C$ (estimated coefficient of PROF variable), Plot D (estimated coefficient of NDTS variable), Plot E (estimated coefficient of GROWTH 
variable), and Plot F (estimated coefficient of SIZE variable). Each plot indicates the variance in the magnitude of parameters, which, in turn, implies that the effects of the capital structure determinants in Equation (3) vary with the levels of the quantile.

First, leverage has a negative relationship with profitability in all distributions; the result obtained by the OLS regression is similar to the sign. Therefore, the existence of profitability in the firm reduces the use of debt as expected. However, at lower quantiles, the profitability has a less negative effect on leverage than at higher quantiles. Ref. [17] also indicate that the absolute effect of profitability increases because Brazilian firms have higher debt ratios. Further, [19] show that, as leverage increases, the absolute significance of profitability increases in Vietnamese firms. We explain the consensus in these results as follows: (1) [17] argue that economic entities tend to rely on internal financing and prefer debt than equity for external financing in several aspects of corporate financing behavior. (2) [5] suppose that when a firm's profitability increases, its retained earnings are subject to more influence. With the other conditions unchanged, firms with more internal financing prefer less external financing and have lower leverage. When this internal source is exhausted, the firms tend to use more external financing. (3) In the POT, asymmetric information cost increases when firms issue debt financing and internal financing as proxies for asymmetric information [7]. Both regression results for Chinese firms, thus, support the prediction of the POT. We find that profitability has significant adverse effects on leverage, which also strongly supports the POT at higher quantiles.

Second, the OLS estimation indicates that GROWTH has a positive and significant relationship with leverage. That is, firms use more debt when they have higher growth opportunities because investment opportunities require strong financing demands. This result corroborates the results in $[7,22]$. For asymmetric information on investment opportunities, the POT predicts that firms prefer using debt over equity as growth opportunity increases. However, the quantile regression results do not exhibit similar signs for all part distributions. The low quantiles $(0.1,0.2)$ reveal a negative effect of growth opportunity on leverage. These results suggest a relationship between less cash flow that is free and greater investment opportunities of a firm with low leverage. In this case, firms are less subject to disciplinary supervision by managers, leading to an inverse effect of investment opportunities on debt. Ref. [10] explain that tangible assets present collateral assets, but intangible assets are inverse. When firms have a higher proportion of intangible assets in total assets (such as growth opportunity), they face more significant difficulties in borrowing debt. Contrariwise, in higher quantiles, the coefficients of growth opportunity are positive and significant. The positive effect of growth opportunity on leverage is more substantial when the debt ratios move to higher levels. Therefore, in higher quantiles, the positive relationship between leverage and growth opportunity offers more support for the POT prediction.

Third, our results show that the coefficients of $L E V_{-1}$ are significant in all distributions, with values ranging from 0.7794 to 0.8922 - that is, the value of $\alpha$ being approximately 0.1078 to 0.2206 . The magnitudes of the $L E V_{-1}$ coefficients are smaller for higher levels of debt. Thus, the speed of the target leverage quickens when the leverage moves to higher levels. Nevertheless, the speed of adjustment to the target leverage of Chinese firms is remarkably low. Ref. [47] argue that, although firms have higher speeds of adjustment, especially over-leveraged ones, the adjustment speeds are still low if they have large amounts of maturing debt. Chinese firms have low adjustment speeds for the target leverage because they have a high proportion of maturity debt in the total debt. This is because a civil law system exists as part of the country's characteristic [48]. The speed of adjustment to target leverage of Chinese firms is approximate with the speed of adjustment to debt maturity in European firms [49], which is slower than in developed countries. According to [15], the annual average of U.S. firms' target leverage is approximate $30 \%$, whereas [50] calculates the speeds of adjustment for a sample of U.K. and Continental European firms to be $48.3 \%$ and $45.6 \%$, respectively. 
Fourth, the negative coefficient of NDTS is estimated by the OLS regression-that is, a non-debt tax shield exists to reduce the necessity of debt. According to [40], depreciations are used as tax deductions. This increases the benefits from taxes and reduces tax debt in the capital structure, thus supporting the TOT assumption. Although NDTS is negative and significant in all parts of the distribution, its coefficients reduce as the leverage quantile moves higher. That is, the effect of the non-debt tax shield on the leverage decreases as the leverages increase. Our finding suggests that the associated benefit of employing depreciation as a non-debt tax shield is lower for higher leverage levels. The quantile regression results indicate that the impact of a non-debt tax shield on leverage is weak when firms use more leverage in the firm's capital structure.

Finally, on the impact of firm size on capital structure decisions in Chinese firms, we find that firm size's estimated coefficients vary in their magnitude and sign because leverage moves up the conditional distribution. However, the OLS estimation insists that firm size positively affects leverage. Ref. [51] explain that larger firms might have easier access to borrowing debt opportunities at better interest rates. Hence, larger firms are characterized by more external financing in their capital structure. At lower quantiles, the quantile regression estimations show that the firm size coefficient has a positively significant sign, as accepted by the TOT. However, firm size coefficients become insignificant at the 80th quantile, changing their sign and significance at the 90th quantile. These results imply that firms might no longer borrow at favorable terms, despite the increasing firm size, because of high leverage. The rise of firm size may depress the marginal agency cost of debt. However, when firms reach high debt ratios, the incremental marginal opportunity cost of binding is higher than the marginal agency cost reduction. Thus, the firm size exerts a negative effect on debt [16]. The results partially corroborate the predictions of both the TOT and the POT. These results also reflect the conclusions proposed by [16,17]. The positive effect of firm size on leverage decreases when Chinese firms issue more debt. At the highest leverage, the negative relationship between firm size and leverage is statistically significant, as predicted by the POT.

Table 5 also reports the results of the homogeneity test and related $p$ values for the parity of quantile parameters when we test the distinct pairs of quantiles: $(0.1 ; 0.9)$, $(0.2 ; 0.8),(0.3 ; 0.7)$, and $(0.4 ; 0.6)$. All F-tests disallowed the null hypothesis, which affirms that all coefficients are homogeneous at the $99 \%$ confidence level for all $F$-tests. Thus, the effects of the independent variables vary across the different quantiles of the debt ratio allocation. These tests affirm that the effect of firm-specific characteristics varies across different quantiles.

\section{Conclusions}

Most prior papers have used conventional linear regressions to investigate capital structure in Chinese firms. Our research uses quantile regression to comprehensively investigate the capital structure of the listed firms in the CSI 300 from 2010 to 2019 at different debt ratio levels. The effect of capital structure determinants on leverage change exists in all distributions.

The empirical results offer robust evidence, indicating that the Chinese firm's capital structure follows the POT and not the TOT. The speed of adjustment to the target debt quickens at higher leverage but remains low in Chinese firms. This implies weak evidence to support the TOT. Although profitability has a negative and significant relationship with leverage in all quantiles, it has a more negative effect on higher quantiles.

This result supports the POT. The negative relationship of growth opportunity leans toward TOT predictions at the low quantiles of leverage. However, the exact positive relationship between growth opportunity and leverage strongly supports the prediction of the POT in higher quantiles. Contrariwise, the non-debt tax shield variable has a less negative effect for high leverage, which offers weaker evidence supporting the TOT. The influence of firm size on leverage is significantly positive in low quantile but weakly negative in high quantiles. Such an effect provides defensive evidence for the POT. 
The overall results partially support the two traditional capital structure theories, with a more substantial POT bias when leverages move to higher levels. That is, the effect of information asymmetry is more robust in firms where debt financing is predominant.

Our study implies that the financial structure of Chinese firms is sustainably explained by the POT theory, even when the tendency of Chinese firms to exploit debts increases in Chinese firms. This result has critical implications for Chinese corporate managers when considering the increased usage of debts in terms of other firm-characteristic factors, as follows. First, Chinese corporate managers decide to increase the usage of debts when corporate profitability tends to decrease, making Chinese enterprises grow faster. Second, larger Chinese enterprises tend to use more debts than small ones. Third, the increased debts in the capital structure of Chinese enterprises enhance the rate of debt adjustment to the target but significantly reduce the non-debt tax shield of Chinese listed firms. Obviously, Chinese corporate managers must be prudent in capital structure decisions because these decisions are tightly involved in other firm features. Nonetheless, our study limits the content of comparison between the two theories, POT and TOT, and ignores the existence of the market timing theory. Another limitation in our study is that the research object is still narrow, limiting the scope of listed companies of the CSI300 index. Therefore, it is hoped that the following studies can develop a broader research model from our study.

Author Contributions: Conceptualization, H.M.N.; Data curation, L.Z., A.I.T. and Y.-C.W.; Formal analysis, L.Z., H.M.N. and Y.-C.W.; Funding acquisition, L.Z.; Investigation, T.H.G.V., F.R., A.I.T. and Y.-C.W.; Methodology, L.Z., Z.L., A.I.T. and Y.-C.W.; Project administration, F.R. and Y.-C.W.; Resources, Z.L. and T.H.G.V.; Validation, Z.L., T.H.G.V. and Y.-C.W.; Visualization, Z.L., T.H.G.V., H.M.N., F.R. and Y.-C.W.; Writing-original draft, Y.-C.W.; Writing-review \& editing, F.R. and Y.-C.W. All authors have read and agreed to the published version of the manuscript.

Funding: This research was funded by National Social Science Foundation of China grant number No. 20BJL127.

Institutional Review Board Statement: Not applicable.

Informed Consent Statement: Not applicable.

Data Availability Statement: The data used to support the findings of this study have not been made available because they belong to Taiwan Economic Journal database.

Acknowledgments: The authors are grateful to the editor and three anonymous referees for their helpful comments and valuable suggestions.

Conflicts of Interest: The authors declare no conflict of interest.

\section{References}

1. Modigliani, F.; Miller, M.H. The cost of capital, corporation finance and the theory of investment. Am. Econ. Rev. 1958, 48, 261-297.

2. Rajan, R.G.; Zingales, L. What do we know about capital structure? Some evidence from international data. J. Financ. 1995, 50, 1421-1460. [CrossRef]

3. Murray, Z.F.; Vidhan, K.G. Testing the pecking order theory of capital structure. J. Financ. Econ. 2003, 67, $217-248$.

4. Hung, J.; Chang, V.Y.L. The analysis of capital structure for property-liability insurers: A quantile regression approach. Bus. Econ. Horiz. 2018, 14, 829-850. [CrossRef]

5. Myers, S.C.; Majluf, N.S. Corporate financing and investment decisions when firms have information that in vestors do not have. J. Financ. Econ. 1984, 13, 187-221. [CrossRef]

6. Titman, S.; Wessels, R. The determinants of capital structure choice. J. Financ. 1988, 43, 1-19. [CrossRef]

7. Fama, E.F.; French, K.R. Testing trade-off and pecking order predictions about dividends and debt. Rev. Financ. Stud. 2002, 15, 1-33. [CrossRef]

8. Yıldırım, D.; Çelik, A.K. Testing the pecking order theory of capital structure: Evidence from Turkey using panel quantile regression approach. Borsa Istanb. Rev. 2021, 21, 317-331. [CrossRef]

9. Akdal, S. How Do Firm Characteristics Affect Capital Structure? Some UK Evidence. Available online: https://ssrn.com/ abstract=1775706 (accessed on 3 March 2011).

10. Myers, S.C. Capital structure. J. Econ. Perspect. 2001, 15, 81-102. [CrossRef]

11. Aquino, R.; Yu, D. Testing capital structure models on Philippine listed firms. Appl. Econ. 2009, 41, $1973-1990$. 
12. Lemmon, M.L.; Zender, J.F. Debt capacity and tests of capital structure theories. J. Financ. Quant. Anal. 2010, 45, 1161-1187. [CrossRef]

13. Graham, J.R. How big are the tax benefits of debt? J. Financ. 2000, 55, 1901-1941. [CrossRef]

14. Bancel, F.; Mittoo, U.R. Cross-country determinants of capital structure choice: A survey of European firms. Financ. Manag. 2004, 10, 103-132.

15. Flannery, M.J.; Rangan, K.P. Partial adjustment toward target capital structures. J. Financ. Econ. 2006, 79, 469-506. [CrossRef]

16. Fattouh, B. Capital structure in South Korea: A quantile regression approach. J. Dev. Econ. 2005, 76, 231-250. [CrossRef]

17. Oliveira, G.R.; Tabak, B.M.; de Lara Resende, J.G.; Cajueiro, D.O. Determinants of the level of indebtedness for Brazilian firms: A quantile regression approach. EconomiA 2013, 14, 123-138. [CrossRef]

18. Sánchez-Vidal, F.J. High debt companies' leverage determinants in Spain: A quantile regression approach. Econ. Model. 2014, 36, 455-465. [CrossRef]

19. Canh, N.T.; Liem, N.T.; Son, T.H. Determinants of capital structure of listed firms in Vietnam: A quantile regression approach. J. Econ. Dev. 2017, 24, 114-131. [CrossRef]

20. Kaloudis, A.; Tsolis, D. Capital structure in US, a quantile regression approach with macroeconomic impacts. J. Econ. Bibliogr. 2018, 5, 1-17.

21. Chen, J.J. Determinants of capital structure of Chinese-listed companies. J. Bus. Res. 2004, 57, 1341-1351. [CrossRef]

22. Tong, G.; Green, C.J. Pecking order or trade-off hypothesis? Evidence on the capital structure of Chinese companies. Appl. Econ. 2005, 37, 2179-2189. [CrossRef]

23. Huang, G. The determinants of capital structure: Evidence from China. China Econ. Rev. 2006, 17, 14-36. [CrossRef]

24. Liu, Y.; Ren, J.; Zhuang, Y. An empirical analysis on the capital structure of Chinese listed I.T. companies. Int. J. Bus. Manag. 2009, 4, 46-51. [CrossRef]

25. Chen, J.; Jiang, C.; Lin, Y. What determine firms' capital structure in China? Manag. Financ. 2013, 40, 1024-1039.

26. Yang, Y. Dynamic capital structure in China: Determinants and adjustment speed. Invest. Manag. Financ. Innov. $2015,12,8$.

27. Kyissima, K.H.; Xue, G.Z.; Kossele, T.P.Y.; Abeid, A.R. Analysis of capital structure stability of listed firms in China. China Financ. Rev. Int. 2020, 10, 213-228. [CrossRef]

28. Vijayakumaran, S.; Vijayakumaran, R. Debt maturity and the effects of growth opportunities and liquidity risk on leverage: Evidence from Chinese listed companies. J. Asian Financ. Econ. Bus. Forthcom. 2019, 6, 27-40. [CrossRef]

29. Bajaj, Y.; Kashiramka, S.; Singh, S. Capital structure dynamics: China and India (Chindia) perspective. Eur. Bus. Rev. 2020, 32, 845-868. [CrossRef]

30. Jiang, X.; Shen, J.H.; Lee, C.C.; Chen, C. Supply-side structural reform and dynamic capital structure adjustment: Evidence from Chinese-listed firms. Pac.-Basin Financ. J. 2021, 65, 101482. [CrossRef]

31. Szomko, N. Factors Associated with the Capital Structure of Polish Companies in the Long and Short Term. Gospod. Nar. Pol. J. Econ. 2020, 301, 55-74. [CrossRef]

32. Ahmed, R.; Bhuyan, R. Capital structure and firm performance in Australian service sector firms: A panel data analysis. J. Risk Financ. Manag. 2020, 13, 214. [CrossRef]

33. Koenker, R.; Bassett, G., Jr. Regression quantiles. Econom. J. Econom. Soc. 1978, 46, 33-50. [CrossRef]

34. Rodriguez, R.N.; Yao, Y. Five things you should know about quantile regression. In Proceedings of the SAS Global Forum 2017 Conference, Orlando, FL, USA, 2-5 April 2017; pp. 2-5.

35. Powell, J.L. Censored regression quantiles. J. Econom. 1986, 32, 143-155. [CrossRef]

36. Buchinsky, M. Estimating the asymptotic covariance matrix for quantile regression models a Monte Carlo study. J. Econ. 1995, 68, 303-338. [CrossRef]

37. Jensen, M.C.; Meckling, W.H. Theory of the firm: Managerial behavior, agency costs and ownership structure. J. Financ. Econ. 1976, 3, 305-360. [CrossRef]

38. Harris, M.; Raviv, A. Capital structure and the informational role of debt. J. Financ. 1990, 45, 321-349. [CrossRef]

39. Harris, M.; Raviv, A. The theory of capital structure. J. Financ. 1991, 46, 297-355. [CrossRef]

40. De Jong, A.; Kabir, R.; Nguyen, T.T. Capital structure around the world: The roles of firm-and country-specific determinants. J. Bank. Financ. 2008, 32, 1954-1969. [CrossRef]

41. DeAngelo, H.; Masulis, R.W. Optimal capital structure under corporate and personal taxation. J. Financ. Econ. 1980, 8, 3-29. [CrossRef]

42. Wald, J.K. How firm characteristics affect capital structure: An international comparison. J. Financ. Res. 1999, 22, 161-187. [CrossRef]

43. Baskin, J. An empirical investigation of the pecking order hypothesis. Financ. Manag. 1989, 18, 26-35. [CrossRef]

44. Warner, J.B. Bankruptcy costs: Some evidence. J. Financ. 1977, 32, 337-347. [CrossRef]

45. Dang, C.; Li, Z.F.; Yang, C. Measuring firm size in empirical corporate finance. J. Bank. Financ. 2018, 86, 159-176. [CrossRef]

46. Aviral, K.T.; Raveesh, K. Determinants of capital structure: A quantile regression analysis. Stud. Bus. Econ. 2015, 10, 16-34. [CrossRef]

47. Hovakimian, A.; Li, G. Do firms have unique target debt ratios to which they adjust? SSRN Electron. J. 2009. [CrossRef]

48. Cotei, C.; Farhat, J.; Abugri, B.A. Testing trade-off and pecking order models of capital structure: Does legal system matter? Manag. Financ. 2011, 37, 715-735. [CrossRef] 
49. Castro, P.; Fernández, M.T.T.; Amor-Tapia, B.; de Miguel, A. Target leverage and speed of adjustment along the life cycle of European listed firms. BRQ Bus. Res. Q. 2016, 19, 188-205. [CrossRef]

50. Wanzenried, G. Capital structure dynamics in the U.K. and continental Europe. Eur. J. Financ. 2006, 12, 693-716. [CrossRef]

51. Smith, C.W., Jr.; Watts, R.L. The investment opportunity set and corporate financing, dividend, and compensation policies. J. Financ. Econ. 1992, 32, 263-292. [CrossRef] 